\title{
Comparative assessment of nutritional composition and physicochemical properties of fresh, freeze- dried and rehydrated rainbow trout (Oncorhynchus mykiss Walbaum, 1792) mince
}

\author{
Bengunur CORAPCI ${ }^{1 *}$ (D), Nilgun GUNERI ${ }^{1}$
}

\begin{abstract}
Freeze drying is known as the excellent drying method for heat sensitive food products. In this research was aimed to determination of nutritional composition and physicochemical properties of fresh, freeze- dried and rehydrated rainbow trout (Oncorhynchus mykiss) mince. Sample groups were established as fresh trout mince, freeze-dried trout mince and rehydrated trout mince after freeze-dried. Proximate composition, $\mathrm{pH}$, water activity, colour measurement, rehydration ratio, fatty acid and amino acid profiles were determined in the samples. As a result; nutritional composition, total aminoacid amounts and total MUFA amounts were different in fresh, freeze dried and rehydrated samples. However; the difference between the total amount of PUFA in fresh and rehydrated samples were found insignificant statistically.
\end{abstract}

Keywords: freeze drying; trout mince; nutrition composition; physicochemical properties.

Practical Application: In this study, which is aimed to use fish mince functionally, the applicability of freeze drying has been tried to be measured. The physicochemical and some nutritional characteristics of the freeze dried and rehydrated trout mince were determined for the first time.

\section{Introduction}

It is recognized that seafood consumption has nutritional and healthiness advantages in mankind (Burger \& Gochfeld, 2009; Rebolé et al., 2015). Fish and other seafood are regarded to be a good source of essential amino acids, polyunsaturated fatty acids, vitamins and minerals (Rebolé et al., 2015). Omega 3 and omega 6 Polyunsaturated fatty acids cannot be synthesized in the human body, they must be received through nourishment (Mahan \& Escott-Stump, 2005; Castro et al., 2007).

Seafood products has been provided by aquaculture production over the past two decades. Farmed fish (specially rainbow trout) has importance in providing n-3 fatty acid sources to consumers (Delgado et al., 2003; Blanchet et al., 2005). Rainbow trout is a valuable source of many important nutrients. It has low fat and calorie values than some foods from the meat group such as red meat and chicken meat. About 3 ounce cooked rainbow trout comprises $22 \mathrm{~g}$ protein, $5 \mathrm{~g}$ fat, $30 \mathrm{mg}$ sodium and $130 \mathrm{cal}$ (Ladewig \& Morat, 1995).

Freeze-drying can be defined as remove by sublimation of water from a frozen material. It provides an opportunity to obtain high quality food products. Because of the absence of liquid water and low temperatures are delayed some of the chemical and microbiological degradation (Rawson et al., 2011).

The advantages of a freeze-dried product are as follows: fast rehydration, retaining good flavour, preserving good color and appearance, prolonged shelf life, reduced transport and storage costs, using simple convenience, minor loss of nutrients (Zhang et al., 2014).

In spite of all these advantages a few seafood products have been dried in using this procedure. There are sliced cod, boiled shrimp, boiled crab and so on. The freeze drying technology are an advisable method for the preservation of seafood products and some problems solving in fishing sector. The freeze dried tuna fish, halibut, trout, whale, shrimp, calamar, octopus, clam, seaurchin, abalone and moss were examined in terms of freeze drying mechanism of marine products (Kobayashi, 1969).

No previous reports focused on the freeze-dried fish mince and nutritional composition, physicochemical and sensory properties. Therefore, the objective of this study was to investigate the nutritional composition and physicochemical properties of fresh, freeze- dried and rehydrated rainbow trout (Oncorhynchus mykiss Walbaum, 1792) mince.

\section{Materials and methods}

\subsection{Sample preparation}

A total of $\mathrm{N}=40$ farmed rainbow trout (Oncorhynchus mykiss Walbaum, 1792) was used in this study. The average body length of the fish was $41.77 \pm 0.26 \mathrm{~cm}$ with weight of $1200 \pm 23.33 \mathrm{~g}$. The fish were obtained from a trout farm in Sinop, Turkey. The fish were brought to the laboratory in iced styropor box. They were eviscerated, beheaded, filleted and washed with iced water. The fish were removed from the bones and skin. Then 
the fish were minced using a blender (Arcelik, K 1260, Turkey) approximately $3 \mathrm{~min}$. (for each lot). The fish mince samples were vacuum packaged using polyamide/polyethylene film $(30 \times 30 \mathrm{~cm}$, COEX, $90 \mu$, oxygen transmission rate of $160 \mathrm{~cm}^{3} / \mathrm{m}^{2} / 24 \mathrm{~h}$ atm at $23{ }^{\circ} \mathrm{C}$ and $0 \%$ relative humidity; carbon dioxide transmission rate of $32 \mathrm{~cm}^{3} / \mathrm{m}^{2} / 24 \mathrm{~h}$ atm at $23^{\circ} \mathrm{C}$ and water vapor transmission rate of $8.5 \mathrm{~g} / \mathrm{m}^{2} / 24 \mathrm{~h}$ atm at $38^{\circ} \mathrm{C}$ ) (Polinas, Turkey). The packaged samples were stored at $-35^{\circ} \mathrm{C}$ until freeze drying.

\subsection{Freeze drying process}

The trout mince samples were transferred to a pilot plant (Gebze Technical University, Chemical Engineering Department, Kocaeli) by the cold chain for freeze drying process within 7 hours. Firstly, the trout mince were thawed (30-45 min) and placed on the freeze dryer tray for efficient drying. Secondly, samples were frozen in a freeze dryer (VirTis Ultra 25 Super $\mathrm{XL}, \mathrm{USA}$ ) at $-35^{\circ} \mathrm{C}$ temperature for $2 \mathrm{hr}$. Then, samples were dried at $+10^{\circ} \mathrm{C}$ shelf temperature, 20 Pa pressure for about $24 \mathrm{hr}$. The freeze dried samples were put into zip lock bag immediately after freeze drying. The freeze-dried fish were cut into small pieces for all analyses (Figure 1).

\subsection{Proximate composition}

The protein value was determined by the Kjeldahl method (Association of Official Analytical Chemists, 1961). Lipids were extracted by the method of Bligh \& Dyer (1959). The moisture content and crude ash content were determined according to the method of Ludorff \& Meyer (1973) and Association of Official Analytical Chemists (1984) respectively.

\subsection{Pysicochemical analyses}

$\mathrm{pH}$ analysis was carried out according to Curran et al. (1980) (Werkstatten 82362 Weilheim, Germany). Water activity and color analyses values were measured according to Association of Official Analytical Chemists (1980) and Schubring (2003), respectively. Rehydration ratio was determined as follows (Equation 1, Giri \& Prasad, 2007):

\subsection{Aminoacid composition}

The amino acid composition values were determined in fresh, freeze dried and rehydrated samples following the procedure described in the literature (Dimova, 2003).

\subsection{Fatty acid analyses}

The fatty acid profiles were carried out according to the method ISO 12966-2:2011 (Demirtas et al., 2013).

\subsection{Statistical analysis}

Experimental data were analysed using of Minitab 15 program (Minitab Inc., State College, PA, USA). It was used one way analysis of variance (ANOVA). For data analysis, mean, standard error were used $(\mathrm{P}<0.05)$. (Ozdamar, 2015).

\section{Results and discussion}

\subsection{Proximate composition}

The proximate composition values of the fresh trout mince, freeze-dried trout mince and rehydrated trout mince were shown in Figure 2.

The moisture value of the freeze-dried trout was reduced to $2.11 \pm 0.01 \%$, and the fat value increased to $23.53 \pm 0.02 \%$. Protein and ash values were increased by $66.41 \pm 0.02 \%$ and $5.20 \pm 0.05 \%$, respectively. Similar consequence has been reported for freeze dried tuna fish (Thunnus tongol) and shark (Rhizoprionodon acutus). (Rahman et al., 2002; Sablani \& Kasapis, 2006). It can be said that the increase in protein, fat and ash values is a proportional increase due to decrease in moisture value.

If there are no contrary effects on the entirety of the tissue structure, it should absorb water to the same moisture content as the original sample before drying (Senadeera et al., 2000; Marques et al., 2009). In our work, it was not possible to recover all of the water after rehydration. This can be said to be due to the loss of water retention capacity of the trout in relation to the texture deterioration of freezing- thawing and freeze-drying process.

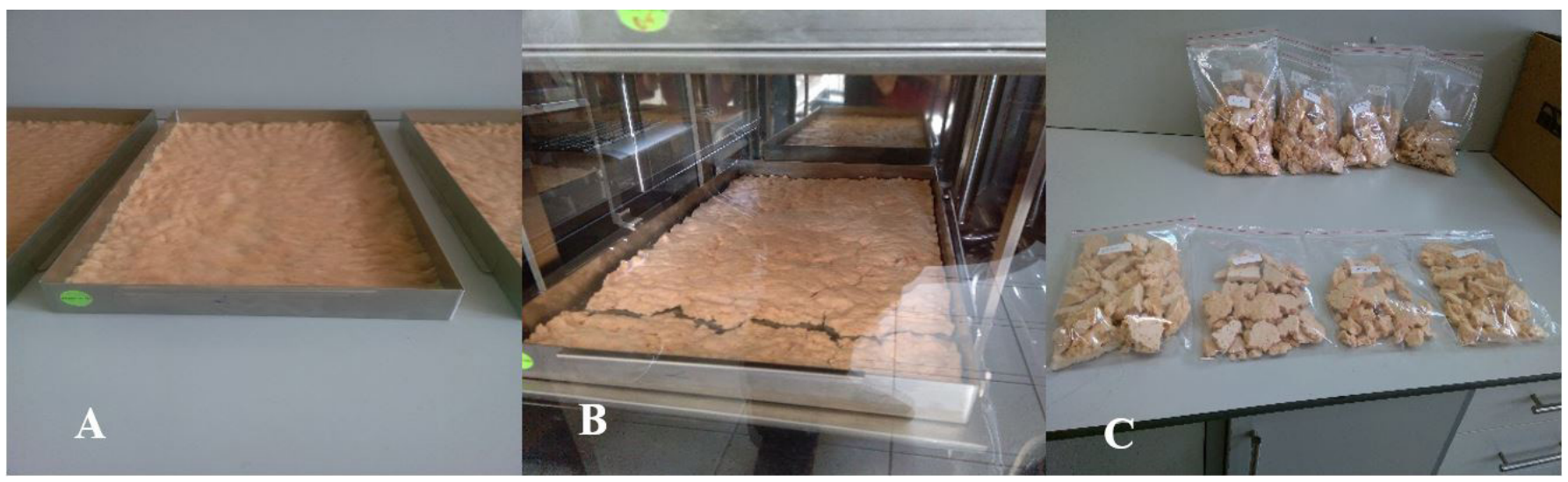

Figure 1. Fresh trout mince (A); Freeze drying process (B); Packaged freeze dried trout mince (C). 


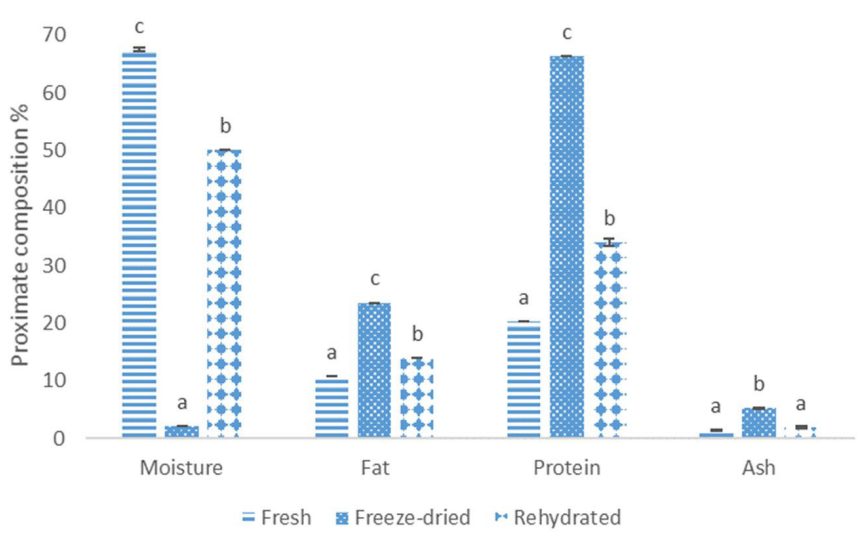

Figure 2. Proximate compositionof fresh trout mince, freeze-dried trout mince and rehydrated trout mince. The same letters of $a, b, c$ point out no significant difference, and the different letters between them mean there is a significant difference, $p<0.05$.

\subsection{Pysicochemical analyses}

$\mathrm{pH}$, water activity values, color measurement of the trout mince samples and rehydration ratio freeze-dried trout mince were shown in Figure 3, Figure 4 and Figure 5.

According to the $\mathrm{pH}$ values, freeze-dried trout were not be affected from freeze-drying process ( $\mathrm{p}>0.05$ ). However, $\mathrm{pH}$ value of rehydrated trout mince were decreased $(\mathrm{p}<0.05)$. A very low water activity value was obtained after freeze drying and this value was slightly above the fresh fish value after rehydration. The difference between the water activity values of fresh and rehydrated samples was not significant ( $p>0.05)$. No microbial activity has been reported in dried aquatic products with water activity below 0.60 . The decrease in water activity value also limits or prevents enzymatic changes (Varlık et al., 2004).

We did not encounter the literature related to freeze dried and rehydrated trout of L, $a^{*}$ and $b^{*}$ values. However, studies of color values of freeze-dried cod and tuna fish were found. Eikevik et al. (2005), freeze dried the cod fish at different temperatures. They were reported that when the drying temperature decreased the $b^{*}$ value also decreased but the $\mathrm{L}$ value increased. In our work, the $\mathrm{L}$ value was increased by freeze drying. However, the value of $b^{*}$ increased after rehydration. Rahman et al. (2002), reported that they found $\mathrm{L}$ value of $57.20, a^{\star}$ value of 6.48 and $b^{*}$ value of 10.88 for tuna fish freeze-dried and stored for 6 months at $20{ }^{\circ} \mathrm{C}$. The browning of dried products can be understood by the $\mathrm{L}$ value. At high $\mathrm{L}$ values, the brown color of the product is reduced. It has been reported that the highest $\mathrm{L}$ value is seen in freeze-dried products when compared with freeze-dried samples with air-dried and vacuum-dried samples (Rahman et al., 2002).

In present study, rehydration ratios of freeze-dried trout mince were determined in distilled water at $30^{\circ} \mathrm{C}$ and $100^{\circ} \mathrm{C}$. Rehydration ratios of the samples were $2.65 \pm 0.07$ at the 15th minute and $2.72 \pm 0.18$ at the 210 th minute at $30{ }^{\circ} \mathrm{C}$. These values were $2.28 \pm 0.01$ at the 2 nd minute of the rehydration and $2.47 \pm 0.01$ at the 20th minute at $100{ }^{\circ} \mathrm{C}$ (Figure 6).

Rehydration ratio of freeze-dried foods is in general 4-6 times higher than air-dried foods (Meda \& Ratti, 2005).
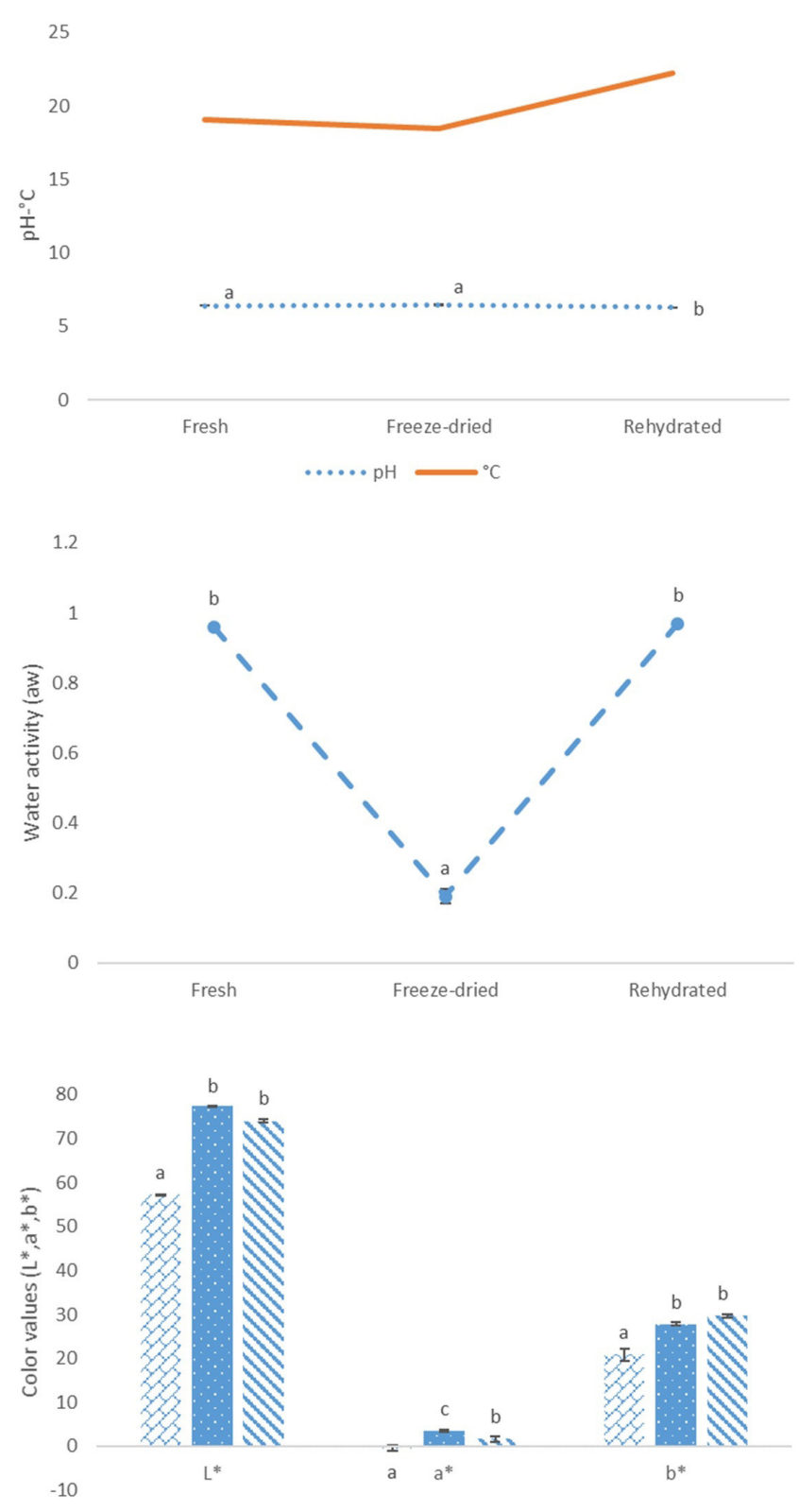

Figure 3. Pysicochemical anayses results of fresh trout mince, freeze-dried trout mince and rehydrated trout mince. The same letters of a, b, c point out no significant difference, and the different letters between them mean there is a significant difference, $p<0.05$.

Generally, dried fish samples is soaked in water before cooking or consumption, thus rehydration is one of the critical quality criteria for dried fish products (Lewicki, 1998; Rahman \& Perera, 1999; Rahman et al. 2002).

He et al. (2012) reported that rehydration ratio as 2.15 in the 30th minute and 2.21 in the 60th minute of freeze-dried crab. It can be said that the value of the rehydration ratio are close to our study. In our study, rehydration ratio that determined in the distilled water at $30^{\circ} \mathrm{C}$ was higher than rehydration ratio measured at $100^{\circ} \mathrm{C}$. It is thought that the reason for this is denaturation of 


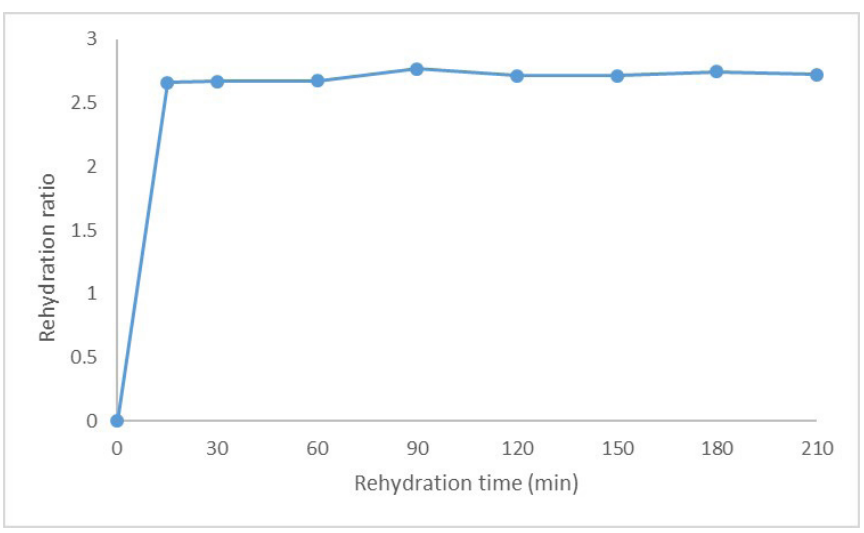

Figure 4. Rehydration ratio of freeze dried trout mince samples at $30{ }^{\circ} \mathrm{C}$ water temperature.

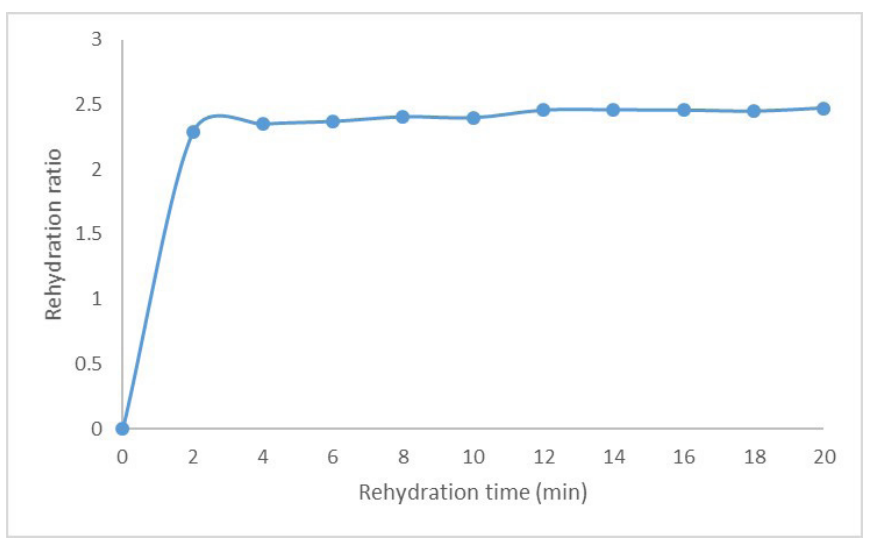

Figure 5. Rehydration ratio of freeze dried trout mince samples at $100^{\circ} \mathrm{C}$ water temperature.

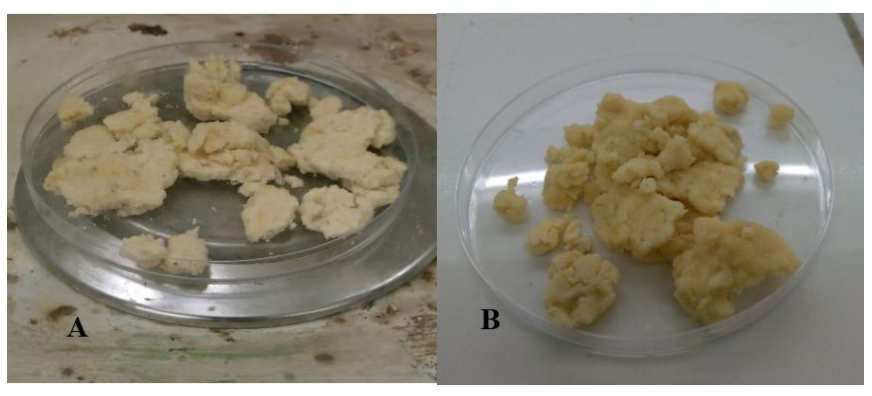

Figure 6. Freeze dried trout mince before rehydration (A) Freeze dried trout mince after rehydration (B).

proteins during the rehydration process at $100{ }^{\circ} \mathrm{C}$ is associated with the detrimental effect of the textural properties and thus the reduction of rehydration capacity.

\subsection{Aminoacid composition}

The aminoacid composition values of the fresh trout mince, freeze-dried trout mince and rehydrated trout mince were shown in Table 1.

In our study of amino acid values in fresh, freeze-dried and rehydrated fish, it was determined that the fresh trout had the highest content of lysine $(2.81 \mathrm{~g} / 100 \mathrm{~g})$ of essential amino acids. After freeze drying, leucine $(6.53 \mathrm{~g} / 100 \mathrm{~g})$ was detected at the highest level compared to other amino acids. Although the amount of leucine after rehydration showed decrease compared to the freeze-dried product $(3.12 \mathrm{~g} / 100 \mathrm{~g})$, it was determined that all amino acids contained the highest leucine content.

It is observed that the amounts of amino acids increase after freeze drying in our work. There are very few studies in the literature evaluating the amino acid content of freeze dried aquaculture products. In a study examining the amino acid compositions of three different species of jellyfish, oven dried and freeze dried jellyfish were compared. According to this; it can be said that jellyfish treated with freeze drying contains amino acids at higher levels than those dried in the oven (Kogovsek et al., 2014). In another study; different drying methods were applied to sea cucumber and their amino acid contents were examined. Compared with the amino acid contents of fresh and freeze dried sea cucumber, certain amino acids are found to increase, while others decrease. However, the total amount of amino acid was determined as 74.80 in fresh sea cucumber and reported as 73.24 in freeze dried sea cucumber (Duan et al., 2010).

In our study, the increase in the amino acid values of the freeze-dried trout and the decrease in the amino acid values of rehydrated samples is thought to be related to proportional water loss. It is also believed that the reduction in the amount of amino acid relative to freeze-dried samples in rehydrated samples is related to denaturation of the proteins as a result of rehydration by immersion of product the distilled water at $100^{\circ} \mathrm{C}$, or to the passage and loss of water-soluble proteins. As a matter of fact, the structure of fish proteins can be easily changed by changing the physical environment. It has been reported that the solubility properties of myofibrillar proteins change after freeze drying (Spinelli et al., 1972; Huss, 1995).

\subsection{Fatty acid composition}

The fatty acid composition values of fresh trout mince, freeze-dried trout mince and rehydrated trout mince were shown in Table 2.

The highest amount of SFA was measured in all groups as palmitic acid (C16:0), and in fresh, freeze-dried and rehydrated trout, $14.79 \pm 0.08 \%, 14.32 \pm 0.00$ and $14.27 \pm 0.00$, respectively. The highest MUFA was oleic acid (C18: $1 \mathrm{n}-9$ ), $30.02 \pm 0.02 \%$, $29.51 \pm 0.01$ and $30.09 \pm 0.00 \%$ in fresh, freeze-dried and rehydrated trout samples, respectively. The lowest MUFA was found to be $0.03 \pm 0.00 \%$ myristicoleic acid (C14: 1) in all three groups. The highest PUFA was determined as linoleic acid (C18:2 n-6) in all three groups. Also, the lowest PUFA was measured in all groups as eicosatrienoic acid (C20:3 n-3).

Çelik et al. (2008), investigated the fatty acid profile of fresh trout (Oncorhynchus mykiss). They were reported that total saturated fatty acids, total monounsaturated fatty acids and total polyunsaturated fatty acids amounts as $27.65 \%, 35.56 \%$ and $23.09 \%$, respectively. It can be said that these results are close to the results of our study. Murphy et al. (2003) investigated the fatty acid and sterol composition of frozen and freeze-dried mussel (Perna canaliculus) from three sites in New Zealand. According 
Table 1. Aminoacid compositionof fresh trout mince, freeze-dried trout mince and rehydrated trout mince $(\mathrm{g} / 100 \mathrm{~g})$.

\begin{tabular}{|c|c|c|c|}
\hline Amino acid $(\mathrm{g} / 100 \mathrm{~g})$ & Fresh & Freeze-dried & Rehydrated \\
\hline Alanine & $0.70 \pm 0.02^{\mathrm{a}}$ & $2.82 \pm 0.13^{c}$ & $1.97 \pm 0.02^{\mathrm{b}}$ \\
\hline Aspartic acid & $2.26 \pm 0.02^{\mathrm{a}}$ & $4.57 \pm 0.01^{\mathrm{c}}$ & $2.98 \pm 0.02^{\mathrm{b}}$ \\
\hline Methionine* & $0.52 \pm 0.00^{\mathrm{a}}$ & $2.53 \pm 0.01^{\mathrm{c}}$ & $1.15 \pm 0.00^{\mathrm{b}}$ \\
\hline Glutamic acid & $2.43 \pm 0.00^{\mathrm{a}}$ & $5.39 \pm 2.79^{c}$ & $2.81 \pm 0.03^{b}$ \\
\hline Phenylalanine ${ }^{*}$ & $0.63 \pm 0.00^{\mathrm{a}}$ & $3.57 \pm 0.01^{\mathrm{c}}$ & $1.64 \pm 0.01^{\mathrm{b}}$ \\
\hline Lysine ${ }^{\star}$ & $2.81 \pm 0.00^{\mathrm{a}}$ & $6.04 \pm 0.01^{\mathrm{b}}$ & $2.96 \pm 0.03^{\mathrm{a}}$ \\
\hline Histidine $^{*}$ & $0.65 \pm 0.00^{\mathrm{a}}$ & $2.21 \pm 0.02^{\mathrm{c}}$ & $1.04 \pm 0.01^{\mathrm{b}}$ \\
\hline Tryosine & $0.56 \pm 0.00^{\mathrm{a}}$ & $2.93 \pm 0.01^{\mathrm{c}}$ & $1.31 \pm 0.01^{\mathrm{b}}$ \\
\hline Glycine & $0.93 \pm 0.00^{\mathrm{a}}$ & $4.20 \pm 0.01^{\mathrm{c}}$ & $1.63 \pm 0.02^{\mathrm{b}}$ \\
\hline Valine* & $0.67 \pm 0.00^{\mathrm{a}}$ & $3.32 \pm 0.00^{c}$ & $1.84 \pm 0.01^{\mathrm{b}}$ \\
\hline Leucine ${ }^{*}$ & $1.30 \pm 0.00^{\mathrm{a}}$ & $6.53 \pm 0.04^{c}$ & $3.12 \pm 0.01^{\mathrm{b}}$ \\
\hline Isoleucine ${ }^{*}$ & $0.80 \pm 0.00^{\mathrm{a}}$ & $4.65 \pm 0.03^{c}$ & $2.05 \pm 0.02^{\mathrm{b}}$ \\
\hline Threonine* & $1.50 \pm 0.00^{\mathrm{a}}$ & $5.35 \pm 0.01^{\mathrm{c}}$ & $2.46 \pm 0.03^{b}$ \\
\hline Serine & $0.91 \pm 0.00^{\mathrm{a}}$ & $2.93 \pm 0.01^{c}$ & $1.61 \pm 0.01^{\mathrm{b}}$ \\
\hline Proline & $0.91 \pm 0.02^{\mathrm{a}}$ & $4.24 \pm 0.09^{\mathrm{b}}$ & $1.41 \pm 0.01^{\mathrm{a}}$ \\
\hline Arginine* & $0.44 \pm 0.00^{\mathrm{b}}$ & $0.61 \pm 0.00^{c}$ & $0.39 \pm 0.00^{\mathrm{a}}$ \\
\hline Total amino acid & $18.11 \pm 0.00^{c}$ & $61.96 \pm 0.18^{\mathrm{a}}$ & $30.44 \pm 0.31^{\mathrm{b}}$ \\
\hline Total essential amino acids (E) & $9.35 \pm 0.00^{c}$ & $34.84 \pm 0.13^{\mathrm{a}}$ & $16.69 \pm 0.15^{b}$ \\
\hline Total non-essential amino acids (NE) & $8.76 \pm 0.00^{c}$ & $27.11 \pm 0.04^{\mathrm{a}}$ & $13.75 \pm 0.15^{\mathrm{b}}$ \\
\hline $\mathrm{E} / \mathrm{NE}$ & $1.06 \pm 0.00^{c}$ & $1.28 \pm 0.00^{\mathrm{a}}$ & $1.21 \pm 0.00^{\mathrm{b}}$ \\
\hline
\end{tabular}

Data are expressed as mean \pm SE $(n=2)$. Means \pm SE follow by the same letter, within a row, are not significantly different $(\mathrm{p}<0.05)$. Essential amino acids $(\mathrm{E})^{*}$, Non-Essential amino acids (NE).

Table 2. Fatty acid compositionof fresh trout mince, freeze-dried trout mince and rehydrated trout mince (\%).

\begin{tabular}{|c|c|c|c|}
\hline Fatty acids & Fresh & Freeze-dried & Rehydrated \\
\hline $\mathrm{C} 12: 0$ & $0.03 \pm 0.02^{\mathrm{a}}$ & $0.04 \pm 0.00^{\mathrm{a}}$ & $0.05 \pm 0.00^{\mathrm{a}}$ \\
\hline C13:0 & $0.01 \pm 0.00^{\mathrm{a}}$ & $0.01 \pm 0.00^{\mathrm{a}}$ & $0.01 \pm 0.00^{\mathrm{a}}$ \\
\hline C14:0 & $2.23 \pm 0.01^{\mathrm{a}}$ & $2.13 \pm 0.00^{\mathrm{b}}$ & $2.14 \pm 0.00^{\mathrm{b}}$ \\
\hline C15:0 & $0.25 \pm 0.00^{\mathrm{a}}$ & $0.26 \pm 0.00^{\mathrm{a}}$ & $0.26 \pm 0.00^{\mathrm{a}}$ \\
\hline $\mathrm{C} 16: 0$ & $14.79 \pm 0.08^{\mathrm{a}}$ & $14.32 \pm 0.00^{\mathrm{b}}$ & $14.27 \pm 0.00^{\mathrm{b}}$ \\
\hline $\mathrm{C} 17: 0$ & $0.21 \pm 0.00^{\mathrm{a}}$ & $0.26 \pm 0.00^{\mathrm{b}}$ & $0.26 \pm 0.00^{\mathrm{b}}$ \\
\hline C18:0 & $4.28 \pm 0.00^{\mathrm{a}}$ & $4.41 \pm 0.00^{\mathrm{b}}$ & $4.52 \pm 0.00^{c}$ \\
\hline $\mathrm{C} 20: 0$ & $0.25 \pm 0.00^{\mathrm{a}}$ & $0.32 \pm 0.00^{\mathrm{b}}$ & $0.27 \pm 0.00^{\mathrm{a}}$ \\
\hline $\mathrm{C} 21: 0$ & $0.04 \pm 0.00^{\mathrm{a}}$ & $0.01 \pm 0.00^{\mathrm{b}}$ & nd \\
\hline $\mathrm{C} 22: 0$ & $0.13 \pm 0.00^{\mathrm{a}}$ & $0.14 \pm 0.00^{\mathrm{b}}$ & $0.14 \pm 0.00^{\mathrm{b}}$ \\
\hline $\mathrm{C} 23: 0$ & $0.01 \pm 0.00^{\mathrm{a}}$ & nd & $0.02 \pm 0.00^{\mathrm{b}}$ \\
\hline C24:0 & $0.05 \pm 0.00^{\mathrm{a}}$ & $0.06 \pm 0.00^{\mathrm{a}}$ & $0.06 \pm 0.00^{\mathrm{a}}$ \\
\hline$\Sigma$ SFA & $22.30 \pm 0.07^{\mathrm{a}}$ & $21.97 \pm 0.00^{a}$ & $22.01 \pm 0.01^{a}$ \\
\hline C14:1 & $0.03 \pm 0.00^{\mathrm{a}}$ & $0.03 \pm 0.00^{\mathrm{a}}$ & $0.03 \pm 0.00^{\mathrm{a}}$ \\
\hline C16:1 & $3.98 \pm 0.00^{\mathrm{a}}$ & $3.61 \pm 0.00^{\mathrm{b}}$ & $3.58 \pm 0.00^{c}$ \\
\hline C18:1 n-9 & $30.02 \pm 0.02^{\mathrm{a}}$ & $29.51 \pm 0.01^{\mathrm{b}}$ & $30.09 \pm 0.00^{\mathrm{a}}$ \\
\hline C20:1 n-9 & $1.83 \pm 0.01^{\mathrm{a}}$ & $1.78 \pm 0.00^{\mathrm{b}}$ & $1.86 \pm 0.00^{\mathrm{a}}$ \\
\hline C22:1 n-9 & $0.19 \pm 0.00^{\mathrm{a}}$ & $0.19 \pm 0.01^{\mathrm{a}}$ & $0.21 \pm 0.00^{\mathrm{a}}$ \\
\hline C24:1 & $0.19 \pm 0.00^{\mathrm{a}}$ & $0.21 \pm 0.00^{\mathrm{b}}$ & $0.21 \pm 0.00^{\mathrm{b}}$ \\
\hline$\Sigma$ MUFA & $36.25 \pm 0.02^{\mathrm{a}}$ & $35.35 \pm 0.03^{c}$ & $35.98 \pm 0.00^{\mathrm{b}}$ \\
\hline C18:2 n-6 (omega-6) & $21.96 \pm 0.01^{\mathrm{a}}$ & $21.77 \pm 0.03^{\mathrm{b}}$ & $21.79 \pm 0.00^{\mathrm{b}}$ \\
\hline C18:3 n-3 (omega-3) & $2.76 \pm 0.01^{\mathrm{a}}$ & $2.66 \pm 0.00^{\mathrm{b}}$ & $2.63 \pm 0.00^{\mathrm{b}}$ \\
\hline C18:3 n-6 & $0.27 \pm 0.00^{\mathrm{a}}$ & $0.34 \pm 0.00^{\mathrm{b}}$ & $0.32 \pm 0.00^{c}$ \\
\hline $\mathrm{C} 20: 2$ & $1.72 \pm 0.00^{\mathrm{a}}$ & $1.76 \pm 0.00^{\mathrm{b}}$ & $1.76 \pm 0.00^{\mathrm{b}}$ \\
\hline C20:3 n-3 (omega-3) & $0.23 \pm 0.00^{\mathrm{a}}$ & $0.26 \pm 0.00^{\mathrm{b}}$ & $0.23 \pm 0.00^{\mathrm{a}}$ \\
\hline $\mathrm{C} 20: 3 \mathrm{n}-6$ cis & $0.52 \pm 0.00^{\mathrm{a}}$ & $0.61 \pm 0.00^{\mathrm{b}}$ & $0.60 \pm 0.00^{\mathrm{b}}$ \\
\hline C20:4 n-6 & $0.38 \pm 0.00^{\mathrm{a}}$ & $0.47 \pm 0.00^{\mathrm{b}}$ & $0.44 \pm 0.00^{c}$ \\
\hline $\mathrm{C} 22: 2$ & $0.49 \pm 0.01^{\mathrm{a}}$ & $0.49 \pm 0.00^{\mathrm{a}}$ & $0.47 \pm 0.00^{\mathrm{a}}$ \\
\hline $\mathrm{C} 22: 5 \mathrm{n}-3$ & $0.59 \pm 0.00^{\mathrm{a}}$ & $0.68 \pm 0.00^{\mathrm{b}}$ & $0.64 \pm 0.00^{c}$ \\
\hline C20:5 n-3 (EPA, omega-3) & $1.20 \pm 0.00^{\mathrm{a}}$ & $1.31 \pm 0.01^{\mathrm{b}}$ & $1.19 \pm 0.00^{\mathrm{a}}$ \\
\hline C22:6 n-3 (DHA, omega-3) & $5.28 \pm 0.04^{\mathrm{a}}$ & $5.81 \pm 0.01^{\mathrm{b}}$ & $5.35 \pm 0.00^{\mathrm{a}}$ \\
\hline$\Sigma$ PUFA & $35.41 \pm 0.02^{b}$ & $36.18 \pm 0.05^{a}$ & $35.44 \pm 0.01^{b}$ \\
\hline$\Sigma \omega-3$ & $10.06 \pm 0.01^{\mathrm{b}}$ & $10.74 \pm 0.02^{\mathrm{a}}$ & $10.05 \pm 0.01^{\mathrm{b}}$ \\
\hline$\Sigma \omega-6$ & $23.13 \pm 0.00^{\mathrm{a}}$ & $23.19 \pm 0.02^{\mathrm{a}}$ & $23.15 \pm 0.00^{\mathrm{a}}$ \\
\hline$\omega-3 / \omega-6$ & $0.43 \pm 0.00^{\mathrm{b}}$ & $0.46 \pm 0.00^{\mathrm{a}}$ & $0.43 \pm 0.00^{c}$ \\
\hline
\end{tabular}

Data are expressed as mean $\pm \mathrm{SE}(\mathrm{n}=2)$. Means \pm SE follow by the same letter, within a row, are not significantly different $(\mathrm{p}<0.05)$. nd $=$ not detected; $S F A=$ Saturated fatty acid(s); MUFA = Monounsaturated fatty acid(s); PUFA = Polyunsaturated fatty acid(s). 
to the result of study they were reported that some of the amounts of fatty acids increased whereas some decreased. It can be said that these results are similar to our study. In addition, the same investigators have reported that freeze-drying may affect the lipid composition of the mussels. In particular, they have reported that freeze-drying may cause to disappear some volatile fatty acids and may cause isomerization some of other fatty acid. It is thought that such an event might have come to fruition in our work. In another study, Zotte et al. (2014) reported the ratio of total saturated fatty acids in freeze-dried trout (Oncorhynchus mykiss) as $21.12 \%$ and indicated the highest saturated fatty acid as palmitic acid with $13.28 \%$. These results are in parallel with the freeze-dried fatty acid results of our study. In the same study, the amount of total monounsaturated fatty acids in fresh trout was expressed as $20.62 \%$, which was determined as $36.24 \%$ in our study. Total polyunsaturated fatty acids of fresh trout were reported by Zotte et al. (2014) as $57.92 \%$, while in our study this value was found to be $35.40 \%$. It can be said that the difference is due to some environmental factors affecting the biochemical composition of the fish.

\section{Conclusion}

In this study, we determined the nutritional composition and physicochemical properties of fresh, freeze- dried and rehydrated rainbow trout (Oncorhynchus mykiss) mince. According to the nutritional composition results, it can be said that protein, fat, moisture and ash (except rehydrated), amino acid and fatty acids values are affected by freeze drying and rehydration processes. Also, it is thought that the samples are affected by the processes such as frozen transfer and thawing before freeze drying.

The $\mathrm{pH}$ value of fresh trout mince was not affected by freeze drying process but decreased following rehydration. The water activity value of the freeze dried trout mince was determined to the amount that can be prevent the microbial and enzymatic activities. There were no changes in $\mathrm{L}$ and $b^{*}$ value among the freeze dried and rehydrated trout mince samples, while $a^{\star}$ value presented a more reddish tone in the freeze dried trout mince.

In view of the nutritional value of the product, it can also be used as a protein additive to enrich various food products as well as direct consumption.

\section{Acknowledgements}

This work was supported by Sinop University Scientific Research Projects Coordination Unit. Project Number: SÜF-1901-13-06, 2016.

\section{References}

Association of Official Analytical Chemists - AOAC. (1961). Officials methods of analysis. Washington: AOAC.

Association of Official Analytical Chemists - AOAC. (1980). Association of official analytical chemists: water activity: 32.004-32.009 (13th ed.). Washington: AOAC. .

Association of Official Analytical Chemists - AOAC. (1984). Officials methods of analysis. Washington: AOAC.
Blanchet, C., Lucas, M., Julien, P., Morin, R., Gingras, S., \& Dewailly, E. (2005). Fatty acid composition of wild and farmed atlantic salmon (Salmo salar) and rainbow trout (Oncorhynchus mykiss). Lipids, 40(5), 529-531. http://dx.doi.org/10.1007/s11745-005-1414-0. PMid:16094864.

Bligh, E. G., \& Dyer, W. J. (1959). A rapid method of total lipid extraction and purification. Canadian Journal of Biochemistry and Physiology, 37(8), 911-917. http://dx.doi.org/10.1139/o59-099. PMid:13671378.

Burger, J., \& Gochfeld, M. (2009). Perceptions of the risks and benefits of fish consumption: individual choices to reduce risk and increase health benefits. Environmental Research, 109(3), 343-349. http:// dx.doi.org/10.1016/j.envres.2008.12.002. PMid:19193369.

Castro, F. A. F., Sant'Ana, H. M. P., Campos, F. M., Costa, N. M. B., Silva, M. T. C., Salaro, A. L., \& Franceschini, S. C. C. (2007). Fatty acid composition of three freshwater fishes under different storage and cooking processes. Food Chemistry, 103(4), 1080-1090. http:// dx.doi.org/10.1016/j.foodchem.2006.10.002.

Çelik, M., Gökçe, M. A., Başusta, N., Küçükgülmez, A., Taşbozan, O., \& Tabakoğlu, Ş. S. (2008). Nutritional quality of rainbow trout (Oncorhynchus mykiss) caught from the Atatürk dam lake in Turkey. Journal of Muscle Foods, 19(1), 50-61. http://dx.doi.org/10.1111/j.17454573.2007.00099.x.

Curran, C. A., Nicoladies, L., Poulter, R. G., \& Pors, J. (1980). Spoilage of fish from hong kong at different storage temperatures. Tropical Science, 22, 367-382.

Delgado, C. L., Wada, N., Rosegrant, M. W., Meijer, S., \& Ahmed, M. (2003). Fish to 2020: supply and demand in changing global markets. Washington: WorldFish and International Food Policy Research Institute.

Demirtas, I., Pelvan, E., Ozdemir, I. S., Alasalvar, C., \& Ertas, E. (2013). Lipid characteristics and phenolics of native grape seed oils grown in Turkey. European Journal of Lipid Science and Technology, 115(6), 641-647. http://dx.doi.org/10.1002/ejlt.201200159.

Dimova, N. (2003). RP-HPLC analysis of aminoacids with UV-detection. Bulgarian Academy of Science, 56, 75-78.

Duan, X., Zhang, M., Mujumdar, A. S., \& Wang, S. (2010). Microwave freeze drying of sea cucumber (Stichopus japonicus). Journal of Food Engineering, 96(4), 491-497. http://dx.doi.org/10.1016/j. jfoodeng.2009.08.031.

Eikevik, T. M., Strommen, I., Alves-Filho, O., \& Hemmingsen, A. K. T. (2005). Effect of operating conditions on atmospheric freeze dried cod fish. In Proceedings of 3 rd Inter-American Drying Conference (IADV2005). Montreal: CRC Press.

Giri, S. K., \& Prasad, S. (2007). Drying kinetics and rehydration characteristics of microwave-vacuum and convective hot-air dried mushrooms. Journal of Food Engineering, 78(2), 512-521. http:// dx.doi.org/10.1016/j.jfoodeng.2005.10.021.

He, L., Li, F., \& Tang, J. (2012). Fatty acid composition in freeze-dried chinese mitten crabs (Eriocheir sinensis). Open Journal of Marine Science, 2(3), 90-95. http://dx.doi.org/10.4236/ojms.2012.23012.

Huss, H. H. (1995). Quality and quality changes in fresh fish (FAO Fisheries Technical Paper, No. 348). Rome: FAO.

Kobayashi, K. (1969). Studies on freeze-drying mechanism of marine products. Memoirs of the Faculty of Fisheries, Hokkaido University, $17,1-70$.

Kogovsek, T., Tinta, T., Klun, K., \& Malej, A. (2014). Jellyfish biochemical composition: importance of standardised sample processing. Marine Ecology Progress Series, 510, 275-288. http://dx.doi.org/10.3354/ meps10959. 
Ladewig, K.F., Morat, M. (1995). Rainbow trout (Southern Regional Aquaculture Center Publication, No. 224) Stoneville: SRAC.

Lewicki, P. P. (1998). Effect of pre-drying treatment, drying, and rehydration on plant tissue properties. International Journal of Food Properties, 1(1), 1-22. http://dx.doi.org/10.1080/10942919809524561.

Ludorff, W., \& Meyer, V. (1973). Fishe und fisherzeuge (pp. 209-210). Berlin: Verlag Paul Parey.

Mahan, L. K., \& Escott-Stump, S. (2005). Krause, alimentos, nutrição e dietoterapia (11. ed.). São Paulo: Roca.

Marques, L. G., Prado, M. M., \& Freire, J. T. (2009). Rehydration characteristics of freeze-dried tropical fruits. Food Science and Technology, 42, 1232-1237. http://dx.doi.org/10.1016/j.lwt.2009.02.012.

Meda, L., \& Ratti, C. (2005). Rehydration of freeze-dried strawberries at varying temperatures. Journal of Food Process Engineering, 28(3), 233-246. http://dx.doi.org/10.1111/j.1745-4530.2005.00404.x.

Murphy, K. J., Mann, N. J., \& Sinclair, A. J. (2003). Fatty acid and sterol composition of frozen and freeze-dried new zealand green lipped mussel (Perna canaliculus) from three sites in New Zealand. Asia Pacific Journal of Clinical Nutrition, 12(1), 50-60. PMid:12737011.

Ozdamar, K. (2015). Paket programlar ile istatistiksel veri analizi (Vol. 1, 10. Baskı). Turquia: Nisan Kitabevi.

Rahman, M. S., \& Perera, C. O. (1999). Drying and food preservation. In M. S. Rahman (Ed.), Handbook of food preservation (1st ed., pp. 173-216). New York: Marcel Dekker.

Rahman, M. S., Al-Amri, O. S., \& Al-Bulushi, I. M. (2002). Pores and physico-chemical characteristics of dried tuna produced by different methods of drying. Journal of Food Engineering, 53(4), 301-313. http://dx.doi.org/10.1016/S0260-8774(01)00169-8.

Rawson, A., Tiwari, B., Tuohy, M., O’Donnell, C., \& Brunton, N. (2011). Effect of ultrasound and blanching pretreatments on polyacetylene and carotenoid content of hot air and freeze dried carrot discs. Ultrasonics Sonochemistry, 18(5), 1172-1179. http:// dx.doi.org/10.1016/j.ultsonch.2011.03.009. PMid:21486706.
Rebolé, A., Velasco, S., Rodríguez, M. L., Treviño, J., Alzueta, C., Tejedor, J. L., \& Ortiz, L. T. (2015). Nutrient content in the muscle and skin of fillets from farmed rainbow trout (Oncorhynchus mykiss). Food Chemistry, 174, 614-620. http://dx.doi.org/10.1016/j. foodchem.2014.11.072. PMid:25529727.

Sablani, S. S., \& Kasapis, S. (2006). Glass transition and water activity of freeze-dried shark. Drying Technology, 24(8), 1003-1009. http:// dx.doi.org/10.1080/07373930600776175.

Schubring, R. (2003). Colour measurement for the determination of the freshness of fish. In J. B. Luten, J. Oehlenschlager \& G. Olafsdottir (Eds.), Quality of fish from catch to consumer: labelling, monitoring and traceability (pp. 251-263). The Netherlands: Wageningen Academic Publishers.

Senadeera, W., Bhandari, B., Young, G., \& Wijesinghe, B. (2000). Physical property changes of fruits and vegetables during hot air drying. In A. S. Mujumdar (Ed.), Drying technology in agriculture and food sciences (pp. 149-166). Enfield: Science Publishers.

Spinelli, J., Koury, B., \& Miller, R. (1972). Approaches to the utilization of fish for the preparation of protein isolates enzymic modifications of myofibrillar fish proteins. Journal of Food Science, 37(4), 604-608. http://dx.doi.org/10.1111/j.1365-2621.1972.tb02703.x.

Varlık, C., Erkan, N., Ozden, O., Mol, S., \& Baygar, T. (2004). Seafood processing technology (No. 4465). Istanbul: Istanbul University.

Zhang, H., Wang, Z.-Y., Yang, X., Zhao, H.-T., Zhang, Y.-C., Dong, A.-J., Jing, J., \& Wang, J. (2014). Determination of free amino acids and 18 elements in freeze-dried strawberry and blueberry fruit using an Amino Acid Analyzer and ICP-MS with micro-wave digestion. Food Chemistry, 147, 189-194. http://dx.doi.org/10.1016/j. foodchem.2013.09.118. PMid:24206704.

Zotte, A. D., Ottavian, M., Concollato, A., Serva, L., Martelli, R., \& Parisi, G. (2014). Authentication of raw and cooked freeze-dried rainbow trout (Oncorhynchus mykiss) by means of near infrared spectroscopy and data fusion. Food Research International, 60, 180-188. http:// dx.doi.org/10.1016/j.foodres.2013.10.033. 